\title{
Nutrients and biomass spatial patterns in alpine tundra ecosystem on Changbai Mountains, Northeast China
}

\author{
Gang $\mathrm{Wu}^{\mathrm{a}}$, Ping Jiang ${ }^{\mathrm{a}, \mathrm{b}, \mathrm{d}}$, Jing Wei ${ }^{\mathrm{a}, \mathrm{c}}$, Hongbo Shao ${ }^{\mathrm{a}, \mathrm{c}, *}$ \\ a State Key Laboratory of Urban and Regional Ecology, Research Center for Eco-Environmental Sciences, \\ Chinese Academy of Sciences, Beijing 100085, China \\ ${ }^{\mathrm{b}}$ Institute of Applied Ecology, Chinese Academy of Sciences, Shenyang 110016, China \\ ${ }^{\mathrm{c}}$ Institute of Life Sciences, Qingdao University of Science \& Technology, Qingdao 266042, China \\ d The Graduate School of Chinese Academy of Sciences, Beijing 100039, China \\ Received 21 May 2007; accepted 22 June 2007 \\ Available online 28 June 2007
}

\begin{abstract}
Biomass and nutrients were investigated in 2003, 2004 and 2005 growing seasons by using a chronosequence of five vegetation types in alpine tundra on Changbai Mountains. The objective of this study was to test whether nutrients at biointerfaces were significant differences among five vegetation types. The biomass and elevation are highly related (biomass $=-237.3 \ln \left(\right.$ elevation) $+494.36 ; R^{2}=0.8092 ; p<0.05$ ). There were no significant differences in phosphorus $(\mathrm{P})$ and sulphur $(\mathrm{S})$ concentrations of roots, stems and leaves among five vegetation types while there are significant differences in nitrogen $(\mathrm{N})$ and $\mathrm{P}$ stocks of roots, stems and leaves and in $\mathrm{S}$ stock of stems and leaves among typical alpine tundra vegetation (TA), meadow alpine tundra vegetation (MA), and swamp alpine tundra vegetation (SA) $(p<0.05)$. Vegetation nutrients stock is averagely $72.46 \mathrm{~kg} \mathrm{hm}^{-2}$, and N, P, S stocks are $48.55,10.33$ and $13.61 \mathrm{~kg} \mathrm{hm}^{-2}$, respectively. Soil $\mathrm{N}$ and S concentrations in MA are significantly higher than those in other four soil types. $\mathrm{P}$ is higher in SA $(p<0.05)$. Soil nutrients stock $(0-20 \mathrm{~cm})$ is averagely $39.59 \mathrm{thm}^{-2}$, and $\mathrm{N}, \mathrm{P}, \mathrm{S}$ stocks are $23.74,5.86$ and $9.99 \mathrm{thm}^{-2}$, respectively.
\end{abstract}

(C) 2007 Elsevier B.V. All rights reserved.

Keywords: Biointerface; Biomass; Nutrients stock; Vegetation type

\section{Introduction}

The climate change has been one of hotspots in global environment issues. Future temperature changes in high latitude regions (alpine tundra) are believed to be larger than any other part of the globe. Although such predictions have uncertainties, it is suggested that by 2080 arctic regions will experience

Abbreviations: FA, Felsenmeer alpine tundra vegetation; LA, lithic alpine tundra vegetation; TA, typical alpine tundra vegetation; MA, meadow alpine tundra vegetation; SA, swamp alpine tundra vegetation; NPP, net primary productivity; N, nitrogen; $\mathrm{P}$, phosphorus; S, sulphur; CDS, cold desert alpine tundra soil; LS, lithic alpine tundra soil; GS, grey alpine tundra soil; MS, meadow alpine tundra soil; PS, peat alpine tundra soil; UNESCO, United Nations Educational, Scientific, and Cultural Organization

* Corresponding author at: Institute of Life Sciences, Qingdao University of Science \& Technology, Qingdao 266042, China. Tel.: +86 10 82428491; fax: +861062943822.

E-mail address: shaohongbochu@126.com (H. Shao). temperature increases of $4-7.5^{\circ} \mathrm{C}$ in summer and $2.5-14^{\circ} \mathrm{C}$ in winter $[1,2]$. Although alpine tundra is one of the most sensitive ecosystems to global climate change in the world, most of studies were only focused on tropical areas [3-5], and few studies were done on change of soil carbon stock associated with soil nutrients in temperate alpine tundra ecosystems previously [6,7]. The last volcano eruption undergone by alpine tundra on Changbai Mountains in 1702 year constitutes a major recurring disturbance and leads to the establishment of shrubs or herbs communities. Now alpine tundra on Changbai Mountains is covered with abundant gramineous grasses, low shrubs or subshrubs, weeds, mosses and lichens [8]. Many studies have shown that in pioneer stages of succession, dominant species modify their environment in the short- or long-term, with effects on the vegetation dynamics [9]. Whereas the post-volcano successions have mainly been studied from a floristical and structural point of view, biomass or nutrients approaches to explain the vegetation dynamics are scarce. Because of the harsh climate of alpine tundra, vegetation productivity is often limited by 
nutrients availability $[10,11]$. High rates of productivity depend strongly on species selection, nutrients availability, nutrients use efficiency, etc. Nutrients limitations are common during plant growth, especially for $\mathrm{N}$ and $\mathrm{P}$. In general, biomass and soil nutrients change substantially with plant age. Biomass over time may differ among species, which is due to in part nutrients availability of different species over time $[9,12] . \mathrm{P}$ is the primary limiting nutrients in alpine tundra, although the degree of limitation varies markedly across the heterogeneous tundra landscape $[13,14]$. For instance, in the North American arctic, NPP in moist tussock tundra tends towards co-limitation by $\mathrm{N}$ and $\mathrm{P}$ whereas wet sedge tundra is typically $\mathrm{P}$-limited $[15,16]$. Mesic tundra probably tends towards $\mathrm{N}$ limitation, although the biological demand for $\mathrm{P}$ in all tundra environments is likely to be enhanced by the current low rates of reactive $\mathrm{N}$ deposition from the atmosphere [17-20]. Otherwise, there is increasing evidence that, for a number of forests, $\mathrm{P}$ is immobilized in the first stages of decomposition to a significantly greater extent than N. Furthermore, most plant $\mathrm{N}$ was tied into perennial, woody stems or coarse roots and contributed little to the annual cycling of nutrients between plant and soil [21,22]. Most organically bound nutrients were fixed in the soil and litter and a low proportion was in biomass in any alpine tundra ecosystem. For instance, the vegetation contained $<35 \%$ of ecosystem $\mathrm{N}$ pool while the remaining $65 \%$ was fixed in the recalcitrant soil organic matter and in the litter in Swedish arctic tundra. As in mesic dwarf shrub tundra and in Betula and Salix dominated shrub tundra, $\mathrm{N}$ percentage in soil plus litter increased to between 90 and $95 \%$ and only $5 \pm 10 \%$ of ecosystem was incorporated into vegetation biomass [22,23]. Consequently, although alpine tundra often contains large pools of nutrients, these are tied into recalcitrant soil organic matter or, when absorbed by plants, a high proportion is locked into tissue with a slow turnover. It is not surprising, therefore, that alpine tundra productivity is generally nutrients limited and that dominant plants are mostly species or functional groups of low nutrients requirement, or species with a conservative use of nutrients [23,24]. Most studies of alpine tundra have either addressed questions of nutrients acquisition or of decomposition and mineralization processes [24-26] while few studies have attempted to integrate processes in both biomass and nutrients. There is currently limited information on nutrients cycling of alpine tundra ecosystems, whereas it is important to better understand nutrients spatial pattern and potential alpine tundra response to environment change in such regions. Alpine tundra occurs on heavily weathered, nutrients-poor soils, and tends to have lower nutrients budgets and a higher proportion of nutrients contained in the living material of ecosystem [27]. Data on biomass and nutrients storage in alpine tundra are limited, and have been the subject of considerable controversy. Clearly, there is a need for additional studies of biomass and nutrients in alpine tundra, and of factors that cause natural variability in biomass and nutrients. Very few studies have assessed effects of soils nutrients on biomass, although investigators have often searched for relationships between soil or drainage features and vegetation composition [28-30].

The aim of this research is to examine nutrients concentrations and stocks of vegetation and soil in alpine tundra on
Changbai Mountains in which litter has accumulated, as $\mathrm{N}$ or $\mathrm{P}$ is regarded as most limiting in vegetation development [1-8] and to study change of biomass and nutrients, therefore we investigated biomass and nutrients in alpine tundra on Changbai Mountains. The above- and below-ground biomass was harvested and soil samples were collected in permanent plots at the end of growing seasons in 3 successive years.

\section{Materials and methods}

\subsection{Study site}

Changbai Mountains Nature Reserve $\left(42^{\circ} 24^{\prime} \mathrm{N}, 128^{\circ} 28^{\prime} \mathrm{E}\right)$ is the best-preserved mountainous ecosystem in China, perhaps even in the world and is a designed UNESCO Biosphere Reserve. It is the most representative upland forest ecosystem, containing a range of soils, vegetation, and climate, with distinct altitudinal distributions. The Reserve contains 1337 vascular plant species, including 1250 seed plant species [39], and four vegetation zones [9]: sub-alpine vegetation, evergreen coniferous forest, mixed broadleaf-conifer forest, and larch forest. The alpine tundra on Changbai Mountains lies in $41^{\circ} 53^{\prime}-42^{\circ} 04^{\prime} \mathrm{N}$, $127^{\circ} 57^{\prime}-128^{\circ} 11^{\prime} \mathrm{E}$ between 1950 and $2690 \mathrm{~m}$ a.s.l. and its total area is $15,860 \mathrm{hm}^{2}$, in which, the area of vegetation coverage is $15,190 \mathrm{hm}^{2}$, accounting for $95.78 \%$ of the entire alpine tundra area [30]. The physiognomy includes mainly volcanic physiognomy, glacier physiognomy and ice edge physiognomy. There are many snow packs on the peak. The mean annual radiation is $506.6 \mathrm{~J} \mathrm{~cm}^{-2} \mathrm{a}^{-1}$, the mean annual light time is $2295 \mathrm{~h}$, the mean annual temperature is $-7.4{ }^{\circ} \mathrm{C}$, January mean temperature (the coldest month) is $-23.8^{\circ} \mathrm{C}$, July mean temperature (the warmest month) is $8.4{ }^{\circ} \mathrm{C}$, the highest temperature is $19.2^{\circ} \mathrm{C}$, and the lowest temperature is $-44^{\circ} \mathrm{C}$. The mean annual rainfall is $900-1340 \mathrm{~mm}$. The sampling sites are located at elevations from 1950 to $2650 \mathrm{~m}$ on the northern slope of Changbai Mountains (Figs. 1 and 2).

\subsection{Sampling}

Sampling collection and measurements were conducted in late July and early August of 2003, 2004 and 2005. We selected sampling sites by visual inspection of vegetation, selecting sites subject to minimal anthropogenic disturbances. Four representative transects were allocated with similar aboveground conditions, geomorphic and hydrological conditions in each vegetation type. There were four quadrats in each transect. Each quadrat was sized $1.0 \mathrm{~m} \times 1.0 \mathrm{~m}$. Plants (including roots) were collected with the harvest method at each plot. Nearly all collected plants were in growing season (the most biomass). The soil bulk density was measured at the depths of 5 and $15 \mathrm{~cm}$, and the data of soil bulk densities, which were adjusted for stone content at each vegetation type. Soil samples at each depths of 0-10 and 10-20 cm were collected from each profile to analyze $\mathrm{N}, \mathrm{P}$, and $\mathrm{S}$ concentrations. In all, a total of 128 plant samples and 256 soil samples were collected and measured per year. 


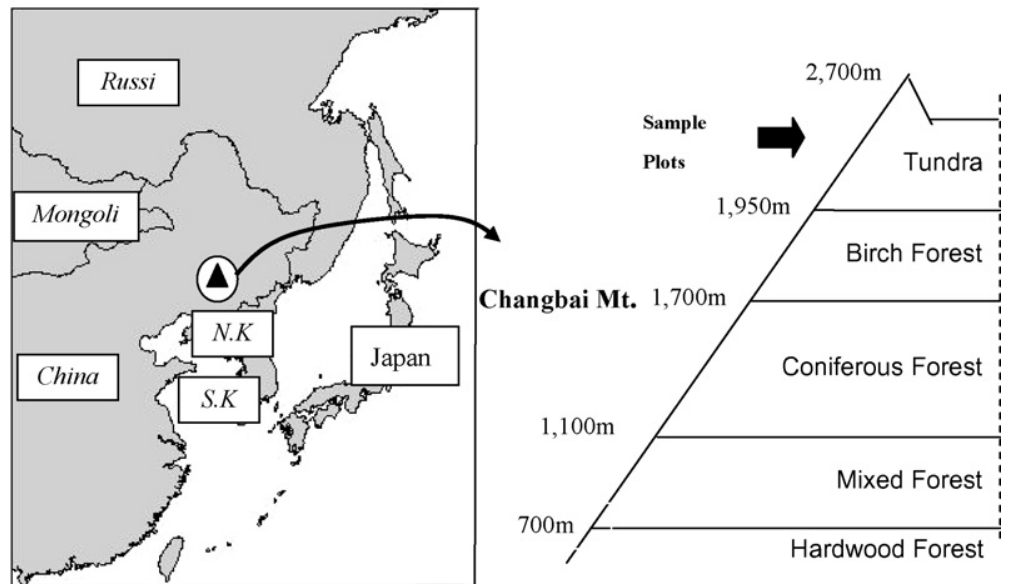

Fig. 1. The sketch of Changbai Mountains Nature Reserve, showing main vegetation types. The sampling sites were located at the elevation from 1950 to $2650 \mathrm{~m}$. The area of studied tundra is $15,195 \mathrm{hm}^{2}$, including five vegetation types and five soil types. Vegetation types are Felsenmeer alpine tundra vegetation, lithic alpine tundra vegetation, typical alpine tundra vegetation, meadow alpine tundra vegetation, and swamp alpine tundra vegetation. Soil types are cold desert alpine tundra soil, lithic alpine tundra soil, grey alpine tundra soil, meadow alpine tundra soil, and peat alpine tundra soil.

\subsection{Chemical analysis and data}

These samples of plants and soil were collected, placed in paper envelopes and hop-pockets, respectively, and dried in the sun. These samples were oven-dried at $65^{\circ} \mathrm{C}$ upon returning to the laboratory. Dried samples were ground to a fine powder using a ball mill. After that, the plant and soil samples were used to analyze nutrients by standard procedures. Total $\mathrm{N}$ was determined using Kjeldahl procedure followed by colorimetric analysis [12] while total $\mathrm{P}$ and $\mathrm{S}$ using an inductive coupled plasma spectrometry (ICPS) after digestion with $\mathrm{HNO}_{3} / \mathrm{HClO}_{4}$. We used the regression approach to the analysis of variance (ANOVA) in the SPSS statistical software package version 11.0. The significance of effects was tested with the $F$-ratios between mean squares of effects and residuals. When significant differences were evident, multiple range tests of the least significant differences were conducted.

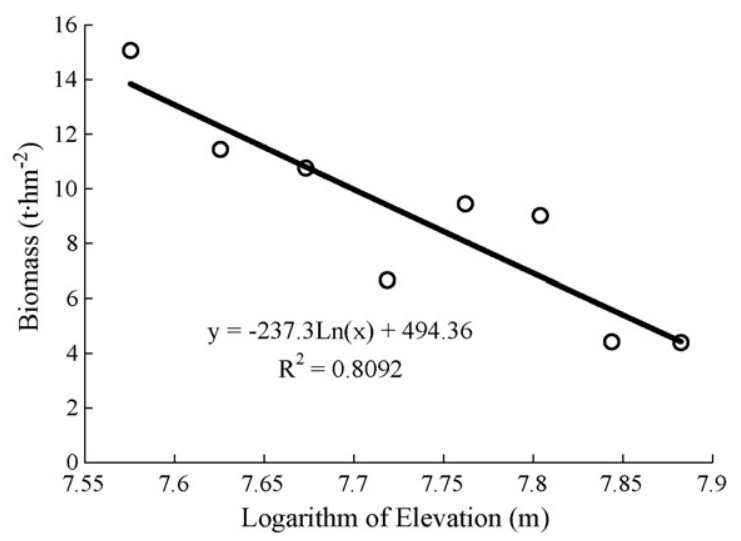

Fig. 2. Relationship between vegetation biomass and elevation in alpine tundra on Changbai Mountains. The $t$-test showed that there are two points largely deviated from the fitted curve. The two points are located at the elevations of 2250 and $2450 \mathrm{~m}$. The $t$-test values are 3.456 (at the elevation of $2250 \mathrm{~m})$ and 4.357 (at the elevation of $2450 \mathrm{~m})\left(n=7, p<0.05, t_{\text {standard }}=1.895\right)$, respectively.

\subsection{Biomass and nutrients budget}

Using biomass of plots and areas of different vegetation types, it could determine vegetation biomass, vegetation carbon storage, and NPP. Using dry weight of plant species and its density, it could calculate the mono-species biomass using the following formula [8]:

$W=\frac{\sum w_{j} n_{j}}{1000}$

where $W$ is mono-species biomass $\left(\mathrm{kg} \mathrm{hm}^{-2}\right), w_{j}$ the average dry weight of the $j$ plant species $\left(\mathrm{g}^{\mathrm{ind}} \mathrm{-}^{-1}\right.$ ) and $n_{j}$ is the number of $j$ plant species (ind. $\mathrm{hm}^{-2}$ ). Using mean values of nutrients and biomass, it could determine vegetation nutrients pools while soil nutrient pools $\left(\mathrm{kg} \mathrm{hm}^{-2}\right)$ were calculated using the following formula [27]:

$P=100 \times \mathrm{NC} \times \mathrm{BD} \times D$

where $\mathrm{NC}$ is the nutrient concentration converted to $\mathrm{g} \mathrm{kg}^{-1}$, BD the soil bulk density in $\mathrm{g} \mathrm{cm}^{-3}$ and $D$ is the soil depth in $\mathrm{cm}$. The soil depth measured at this site was $20 \mathrm{~cm}$.

\section{Results}

\subsection{Biomass pattern in alpine tundra on Changbai Mountains}

\subsubsection{Patterns of vegetation}

There is significant differences of plot biomass in both FA and LA, either aboveground or belowground parts $(p<0.05)$. Root plot biomass in SA is significantly smaller than those in TA and MA while leaves in SA bigger than in TA and MA and stem in TA bigger than in MA and SA $(p<0.05)$ (Table 1). The biomass of 5 vegetation types spatially distributes as follows: $\mathrm{SA}>\mathrm{TA}>\mathrm{MA}>\mathrm{LA}>\mathrm{FA}$ in alpine tundra on Changbai Mountains. 
Table 1

Vegetation biomass pattern in alpine tundra ecosystem on Changbai Mountains

\begin{tabular}{|c|c|c|c|c|c|c|}
\hline Vegetation type & Components & Plot biomass ${ }^{\mathrm{a}}\left(\mathrm{kg} \mathrm{hm}^{-2}\right)$ & Area $\left(\mathrm{hm}^{2}\right)$ & Vegetation biomass $\left(\mathrm{t} \mathrm{hm}^{-2}\right)$ & $\mathrm{NPP}\left(\mathrm{thm}^{-2}\right.$ year $\left.^{-1}\right)$ & Total carbon storage $(\mathrm{t})$ \\
\hline FA & $\begin{array}{l}\text { Belowground } \\
\text { Aboveground }\end{array}$ & $\begin{array}{l}23.82 \pm 2.84 \\
36.18 \pm 7.18\end{array}$ & 85 & 0.06 & 0.06 & 5.1 \\
\hline LA & $\begin{array}{l}\text { Belowground } \\
\text { Aboveground }\end{array}$ & $\begin{array}{r}177^{b} \pm 23.91 \\
73^{b} \pm 13.81\end{array}$ & 4160 & 0.25 & 0.25 & 1040 \\
\hline TA & $\begin{array}{l}\text { Root } \\
\text { Stem } \\
\text { Leaves }\end{array}$ & $\begin{array}{c}1160.32 \pm 110.8 \\
1204.72^{\mathrm{b}} \pm 98.6 \\
594.96 \pm 75.2\end{array}$ & 10870 & 2.96 & 1.48 & 32175.2 \\
\hline MA & $\begin{array}{l}\text { Root } \\
\text { Stem } \\
\text { Leaves }\end{array}$ & $\begin{aligned} 1722.6 & \pm 110.45 \\
655.4 & \pm 98.4 \\
522 & \pm 32.17\end{aligned}$ & 65 & 2.9 & 1.45 & 188.3 \\
\hline SA & $\begin{array}{l}\text { Root } \\
\text { Stem } \\
\text { Leaves }\end{array}$ & $\begin{array}{c}833.98^{\mathrm{b}} \pm 212.7 \\
753.48 \pm 78.3 \\
1632.54^{\mathrm{b}} \pm 213.7\end{array}$ & 15 & 3.22 & 1.61 & 48.3 \\
\hline Total & & 9389.9 & 15195 & 2.21 & 1.14 & 33456.9 \\
\hline
\end{tabular}

${ }^{a}$ Mean value and standard deviation of plot biomass are reported, values behind \pm sign are standard deviation.

b Significant differences at $p<0.05$.

\subsubsection{Relationship between biomass and elevation}

The biomass and elevation are highly related (biomass = $-237.3 \ln ($ elevation $\left.)+494.36 ; R^{2}=0.8092 ; p<0.05\right)$, which shows that vegetation biomass is mainly affected by elevation. From Fig. 2, there are two points largely deviated from the fitted curve by $t$-test values $\left(t_{2250 \mathrm{~m}}=3.456 ; t_{2450 \mathrm{~m}}=4.357, n=7\right.$, $\left.p<0.05, t_{\text {standard }}=1.895\right)$, which are biomass at both elevations of 2250 and $2450 \mathrm{~m}$ (Fig. 2). From the field investigation on the spot and analysis, the deviated points at the elevations of 2250 and $2450 \mathrm{~m}$ are mainly from the reasons that there are many dominant species from high elevation (such as LA and FA) distributed in weather ridge and steep slope at the elevations of $2250 \mathrm{~m}$ and $2450 \mathrm{~m}$ and that there are strong aeolian erosion and snow patch erosion in somewhere and that vegetation coverage is below $20 \%$ in weather ridge and steep slope.

In order to study the correlativity between organ biomass and elevation, it takes an example of dominant species from Ericaceae (such as Rhododendron chrysanthum and Vaccinium uliginosum var. alpinum) to analyze organ biomass distribution. There are significantly different patterns of roots, stems, and leaves biomass along elevation gradient. The root biomass percentage gradually increases along increasing elevation while

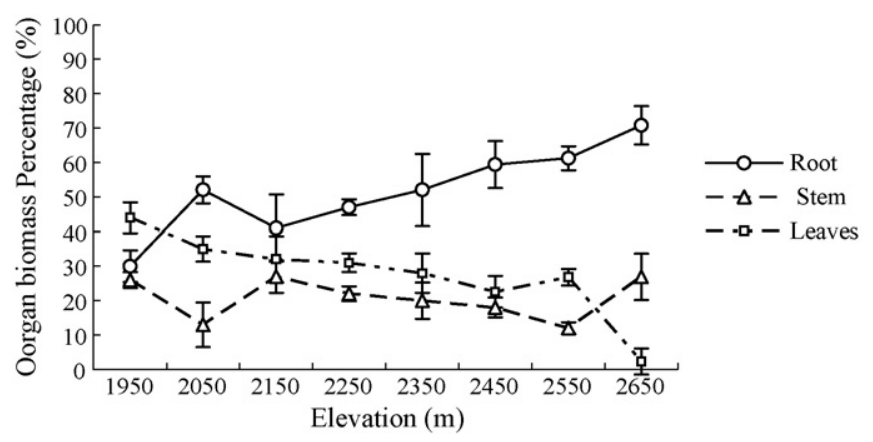

Fig. 3. Organ biomass gradient change of dominant species (i.e. Ericaceae) along elevation. leaves markedly decreases and stem changes irregularly (Fig. 3). Organ biomass of Vaccinium uliginosum var. alpinum (mainly distributed below elevation of $2350 \mathrm{~m}$ ) distributed along increasing elevation as follows: stems $>$ roots $>$ leaves while that of Rhododendron chrysanthum (mainly distributed above elevation of $2450 \mathrm{~m}$ ) roots $>$ stems $>$ leaves. The subtle differences are from different organs of different dominant species long-term adaptation to aeolian or snow erosion.

\subsection{Vegetation nutrients pattern in alpine tundra on Changbai Mountains}

Among the plant components, leaves have the highest N, P, and $\mathrm{S}$ concentrations, with $\mathrm{N}$ being the major nutrients. Although there were no significant differences in $\mathrm{P}$ and $\mathrm{S}$ concentrations among roots, stems and leaves at each vegetation type, $\mathrm{P}$ and $\mathrm{S}$ concentrations are at least 1.5-2 times higher in leaves or aboveground than in roots or belowground. But plant N, $\mathrm{P}$, and $\mathrm{S}$ stocks in both FA and LA, either aboveground or belowground part, are significantly different $(p<0.05)$. There are significant difference in $\mathrm{N}$ and $\mathrm{P}$ stocks of root, stem, and leaves $(p<0.05)$ while there are only significant difference in S stock of stem and leaves among the TA, MA, and SA (Table 2). There are similarly spatial patterns about N, $\mathrm{P}$, and $\mathrm{S}$ concentrations or stocks among 5 vegetation types. Nutrients stock of vegetation is averagely $72.46 \mathrm{~kg} \mathrm{hm}^{-2}, \mathrm{~N}$, $\mathrm{P}$, and $\mathrm{S}$ of which is $48.55,10.33$, and $13.61 \mathrm{~kg} \mathrm{hm}^{-2}$, respectively, in alpine tundra ecosystem on Changbai Mountains (Table 2).

\subsection{Soil nutrients pattern in alpine tundra on Changbai Mountains}

Soil N, P, and S concentrations or stocks are mainly accumulated at the depth of $0-10 \mathrm{~cm}$. Soil $\mathrm{N}$ concentration is greater than soil $\mathrm{P}$ and $\mathrm{S}$. But soil $\mathrm{N}$ and $\mathrm{S}$ concentrations in MA are 
Table 2

Vegetation nutrients concentrations and stocks

\begin{tabular}{|c|c|c|c|c|c|c|c|}
\hline \multirow[t]{2}{*}{ Vegetation type } & \multirow[t]{2}{*}{ Parts } & \multicolumn{2}{|l|}{ Total $\mathrm{N}^{\mathrm{a}}$} & \multicolumn{2}{|l|}{ Total $\mathrm{P}^{\mathrm{a}}$} & \multicolumn{2}{|l|}{ Total $\mathrm{S}^{\mathrm{a}}$} \\
\hline & & $\begin{array}{l}\text { Concentration } \\
\left(\mathrm{g} \mathrm{kg}^{-1}\right)\end{array}$ & Stock $\left(\mathrm{kg} \mathrm{hm}^{-2}\right)$ & $\begin{array}{l}\text { Concentration } \\
\left(\mathrm{g} \mathrm{kg}^{-1}\right)\end{array}$ & Stock $\left(\mathrm{kg} \mathrm{hm}^{-2}\right)$ & $\begin{array}{l}\text { Concentration } \\
\left(\mathrm{g} \mathrm{kg}^{-1}\right)\end{array}$ & Stock $\left(\mathrm{kg} \mathrm{hm}^{-2}\right)$ \\
\hline LA & $\begin{array}{l}\text { Belowground } \\
\text { Aboveground }\end{array}$ & $\begin{aligned} 5.3 & \pm 1.4 \\
15.2 & \pm 11.0\end{aligned}$ & $\begin{array}{l}0.94(0.033) \\
1.12(0.15)\end{array}$ & $\begin{array}{l}2.7 \pm 1.6 \\
3.8 \pm 4.3\end{array}$ & $\begin{array}{l}0.45(0.04) \\
0.28(0.06)\end{array}$ & $\begin{array}{l}1.8 \pm 0.8 \\
1.3 \pm 1.1\end{array}$ & $\begin{array}{l}0.32(0.02) \\
0.09(0.02)\end{array}$ \\
\hline MA & $\begin{array}{l}\text { Root } \\
\text { Stem } \\
\text { Leaves }\end{array}$ & $\begin{array}{l}3.6 \pm 1.2 \\
2.7 \pm 1.3 \\
6.6 \pm 2.1\end{array}$ & $\begin{array}{l}6.2(0.13) \\
1.77(0.13) \\
3.45(0.07)\end{array}$ & $\begin{array}{l}1.2 \pm 0.8 \\
0.8 \pm 0.3 \\
1.2 \pm 1.1\end{array}$ & $\begin{array}{l}2.07(0.03) \\
0.52(0.04) \\
0.63(0.09)\end{array}$ & $\begin{array}{l}0.8 \pm 0.4 \\
1.7 \pm 1.2 \\
1.8 \pm 0.9\end{array}$ & $\begin{array}{l}1.38(0.12) \\
1.11(0.03) \\
0.94(0.15)\end{array}$ \\
\hline
\end{tabular}

${ }^{a}$ Mean value and standard deviation of plant nutrient concentrations or stocks are reported at each component of each vegetation type. Values within parentheses or behind \pm sign are standard deviation.

b Significant differences at $p<0.05$.

significantly higher than those in other four soil types while $\mathrm{P}$ concentration in SA higher $(p<0.05)$ (Table 3). Difference of N concentration throughout the soil layers is not evident $(p<0.05)$, but there is similar pattern between $0-10$ and $10-20 \mathrm{~cm}$. P concentration or stock at the depth of $10-20 \mathrm{~cm}$ soil layer is evidently greater than that at the depth of $0-10 \mathrm{~cm}$ among FA, LA, TA, and MA. S concentration or stock at the depth of $0-10 \mathrm{~cm}$ soil layer is evidently greater than that at the depth of $10-20 \mathrm{~cm}$ among FA, LA, TA, and SA. Nutrients stock of soil $(0-20 \mathrm{~cm})$ is averagely $39.59 \mathrm{thm}^{-2}, \mathrm{~N}, \mathrm{P}$, and $\mathrm{S}$ of which is $23.74^{2}, 5.86$, and $9.99 \mathrm{thm}^{-2}$, respectively, in alpine tundra ecosystem on Changbai Mountains (Table 3).

\section{Discussion}

\subsection{Change of vegetation nutrients}

Plant N, P, and S concentrations or stocks in 5 vegetation types are summarized in Table 2. Although $\mathrm{N}$ stock is the most in TA and SA while P in MA or SA and S in SA, respectively, $\mathrm{N}$ is mainly concentrated in root parts of TA and SA while $\mathrm{P}$ in roots of MA or leaves of SA and S in leaves of SA. On one hand, the nutrients stock differences of 5 vegetation types are from the reason that different dominant species of 5 vegetation types and their organs have the different selective absorption coefficients

Table 3

Soil nutrients concentrations and stocks

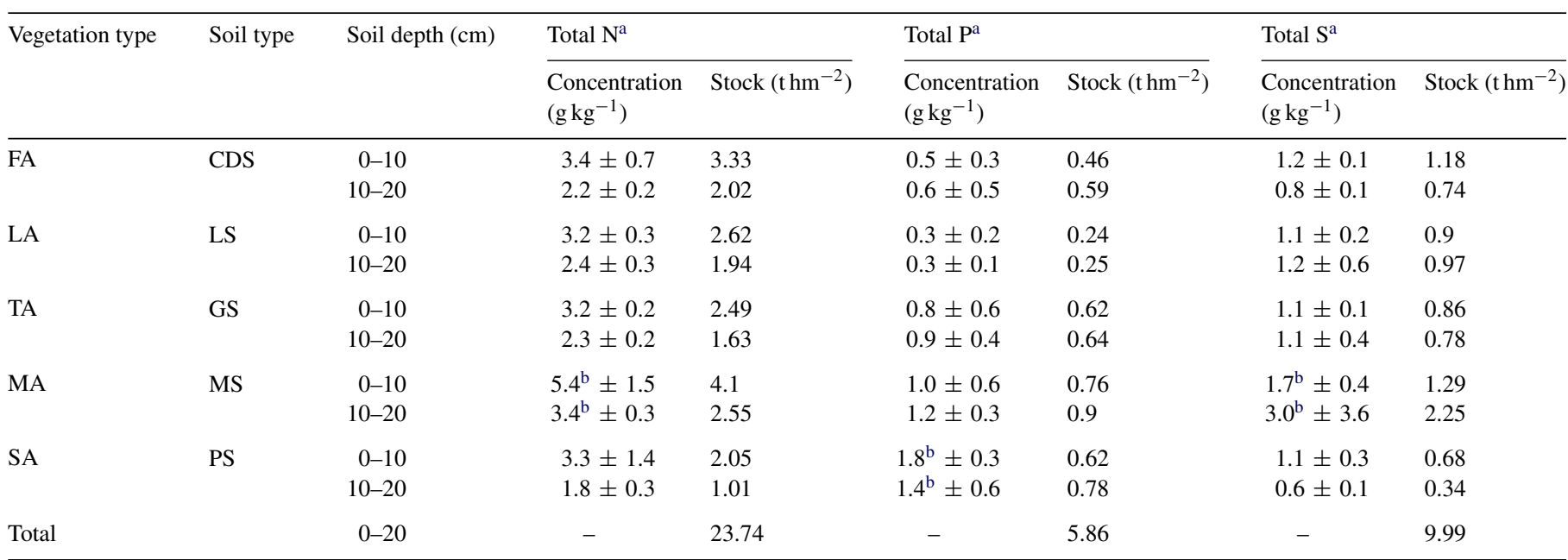

${ }^{a}$ Mean value and standard deviation of soil nutrients concentration and stock are reported at different soil depths of each soil type. Values behind \pm sign are standard deviation.

b Significant differences at $p<0.05$. 
to N, P, and S nutrients. For instance, Polygonum ochotense (main dominant species) is abundant of $\mathrm{N}$ in TA $(0.48 \%)$ and SA $(0.33 \%)$ while Rhododendron confertissimum of $\mathrm{P}$ in MA $(0.13 \%)$ or SA $(0.19 \%)$ and Dryas octopetala var. asiatica of S in SA $(0.22 \%)[5,31,32]$. The other possible reason is that nutrients are probably transferred from aboveground to belowground (root) during the vegetation development after volcano eruption in 1702a. For instance, $\mathrm{N}$ and $\mathrm{P}$ are mobile in the stem (xylem) and can be re-translocated within the dominant plant while the mobility of S from cell to cell and within the phloem is restricted. This needs to be further studied. Joanna et al. [31] reported root $\mathrm{N}$ concentration was $0.90-1.13 \%$ and $\mathrm{P}$ was $0.08-0.12 \%$ in subarctic and arctic ecosystems and in a Pinus patula plantation in South Africa, which is considerably lower than the values reported in this study (Table 2). Although Joanna et al. [31] and this study both examined roots within the various litter/soil layers, the time of root sampling may be relevant as in this study roots were sampled only once per year, during the active growing season. Ideally, roots should be monitored throughout the year to adequately assess biomass, nutrients concentration and uptake.

\subsection{Change of soil nutrients}

Soil nutrients change after human disturbance or natural disaster mainly because (1) human activities and natural disaster could directly affect soil nutrients decomposition and loss; (2) soil moisture is easily affected by climate (e.g., the addition of water to dry soil caused large pulsed of $\mathrm{CO}_{2}, \mathrm{NO}$ and $\mathrm{N}_{2} \mathrm{O}$ emissions [33-38]); (3) pioneer plants or dominant species have different nutrients requirements, exploit nutrients with varying efficiency and store or convert nutrients at different rates [39-41].

Soil $\mathrm{N}$ pattern has a close relation with root system distribution (root clumping and root free zone) [31,33]. Many studies have shown that $\mathrm{N}$-fixing species can significantly increase soil $\mathrm{N}$ levels [34], while others found no correlation between the presence of $\mathrm{N}$-fixing species and total $\mathrm{N}$ accumulation in the surface soil [35,37]. Aron et al. [10] measured soil nutrients concentration of $P$. aristata and $P$. engelmannii alpine tundra at the depth of $10 \mathrm{~cm}$, respectively. It is clear that soil $\mathrm{N}$ concentration in alpine tundra on Changbai Mountains is significantly higher than those in $P$. aristata and $P$. engelmannii alpine tundra (Table 4). In this study we found that surface soil $(0-10 \mathrm{~cm})$ in FA and MA was abundant of $\mathrm{N}$. This possible reason is that $\mathrm{N}$ of plant and litter is very high while $\mathrm{N}$ use efficiency is relatively low [5]; that there is higher net $\mathrm{N}$ mineralization rate from rock weathering during forming soil after volcano eruption; that root system in fixing $\mathrm{N}$ has special spatial pattern.

Differences in soil $\mathrm{P}$ may result from change of biological and geochemical processes at different depths after volcano eruption $[38,39]$. In soil mycorrhizal symbionts and other microorganisms closely couple decomposition and uptake processes contributing to soil $\mathrm{P}$ retention. Biological controls on $\mathrm{P}$ include root growth patterns, amounts and quality of detritus inputs, extracelluar enzyme activity, production of organic chelates and mycorrhizal activity [40,41]. Soil P does not significantly change
Table 4

Contrast soil $\mathrm{N}$ and $\mathrm{P}$ concentrations in this study with Aron [10] $\left(\mathrm{g} \mathrm{kg}^{-1}\right)$

\begin{tabular}{|c|c|c|c|}
\hline Sites & Alpine tundra & $\mathrm{N}^{\mathrm{a}}$ & $\mathrm{P}^{\mathrm{a}}$ \\
\hline \multirow[t]{3}{*}{ Aron et al. [10] sites } & P. aristata & $1.6(0.2)$ & 0.275 \\
\hline & P. engelmannii & $2.3(0.3)$ & 0.35 \\
\hline & Average & $1.9(0.3)$ & 0.315 \\
\hline Alpine tundra on & FA & $2.7(0.9)$ & $0.55(0.41)$ \\
\hline \multirow[t]{5}{*}{ Changbai Mountains } & LA & $2.9(0.6)$ & $0.31(0.21)$ \\
\hline & TA & $3.1(0.4)$ & $0.87(0.57)$ \\
\hline & MA & $4.8(1.2)$ & $0.91(0.66)$ \\
\hline & SA & $2.9(0.9)$ & $1.72(0.73)$ \\
\hline & Average & $3.28(1.25)$ & $0.872(0.78)$ \\
\hline
\end{tabular}

a Values within parentheses are standard deviation.

at 5 vegetation types in alpine tundra on Changbai Mountains. The soil P is lower in LA while higher at the depth of $10-20 \mathrm{~cm}$ in MA. So there is large storage of soil P in MA and SA (Table 4). The details of soil $P$ change at 5 vegetation types appear different and complicated. But it is clear that soil $P$ concentration in alpine tundra on Changbai Mountains is significantly higher than those in $P$. aristata and P. engelmannii alpine tundra [34,37] (Table 4). Although differences in soil nutrients could be a result of heterogeneous soil conditions, we suggested that a more plausible explanation was that $R$. chrysanthum and $R$. confertissimum tree islands were altering soil chemistry of tundra predominantly by their existence and growth in the alpine tundra environment [5-7].

$\mathrm{S}$ is considered an essential plant macronutrient. The factors that control the rate of $\mathrm{S}$ reduction have not been identified with certainty in the various environments because many factors are involved, such as, oxygen and sulphate concentrations, temperature and organic matter availability $[23,26]$. Soil S would come from the mineralization of litter, soil organic matter and rock in alpine tundra on Changbai Mountains. We also found that $\mathrm{S}$ and $\mathrm{P}$ stocks in dominant plants were very high while in soil relatively low, which showed that use efficiency of S and $\mathrm{P}$ was significantly high and that $\mathrm{S}$ and $\mathrm{P}$ were the most limited factors of plant growth in alpine tundra on Changbai Mountains $[6,7]$. Further research should be done to elucidate the relative contribution of soil S and $\mathrm{P}$ during vegetation development after gigantic volcano eruption in $1702 \mathrm{a}$. The ratios of $\mathrm{C}: \mathrm{N}, \mathrm{C}: \mathrm{P}, \mathrm{C}: \mathrm{S}$ and $\mathrm{C}: \mathrm{N}: \mathrm{P}$ were often used as indicators of soil nutrient condition $[8,26,27]$. Soil $\mathrm{N}$ and $\mathrm{S}$ concentrations are lower in SA while soil $\mathrm{P}$ is lower in LA and higher in MA of alpine tundra on Changbai Mountains, respectively. The possible reason is that after volcano eruption, soil is mainly oriented with physical weathering. Furthermore, after vegetation restoration, although plants grow slowly under low temperature, the anaerobic and reductive soil is against decomposition of litter and microorganism, which makes alpine tundra soil abundant of humus or turf bed. Although soil sampling replications were limited in this study, the sampling size satisfied the minimum requirement $(5 \times 4)$ in most of ecological field studies by statistical rule of thumb. However, certain cautions are needed when extending the reported findings in this study. 


\section{Conclusions}

The similarities in biomass or soil nutrients between LA and FA or among TA, MA, and SA would be difficult to anticipate without census information showing the proportionally large number of shrubs and herbs in the community. The sampling area, times, depth and harvesting method may account for the fact that there is significant differences of plant plot biomass in both FA and LA $(p<0.05)$; that root plot biomass in SA is significantly smaller than those in TA and MA while leaves in SA bigger than in TA and MA and stem in TA bigger than in MA and SA $(p<0.05)$; that soil $\mathrm{N}$ and $\mathrm{S}$ concentrations in MA are significantly higher than those in other four soil types while $\mathrm{P}$ in SA higher $(p<0.05)$.

In order to understand effects of different dominant species on alpine tundra of Changbai Mountains, future comparisons should specially focus on the role of dominant species in different alpine tundra types, as well as better understanding about general conclusions regarding nutrients spatial pattern in alpine tundra, which may not hold for cross site comparisons. Future studies should focus on dominant species shift, spatial-temporal pattern change of biomass and litter, nutrients availability, soil activity, $\mathrm{N}, \mathrm{S}$, and $\mathrm{P}$ re-location and causes of plant or soil nutrients differences in alpine tundra on Changbai Mountains.

\section{Acknowledgements}

The study was supported by National Natural Science Foundation of China (No.: 40473054) and Agricultural Technological Production Translation of Science and Technology of Ministry (No.: 05EFN216600446). Special thanks were given to Dr. Qingkang Li from Institute of Botany and Dr. Ji Ye from Institute of Applied Ecology, Chinese Academy of Sciences (CAS) for their suggestions and the Forest Ecosystem Research Station of Changbai Mountains, Chinese Academy of Sciences (CAS) for their support of field investigations and experiments.

\section{References}

[1] G. Wu, J.Z. Zhao, G.F. Shao, Carbon cycling of alpine tundra ecosystem on Changbai Mountains and its comparison study with arctic tundra, Sci. China D 45 (10) (2002) 903-910.

[2] J. Wei, G. Wu, H.-B. Deng, Researches on nutrient return of litterfall in the alpine tundra ecosystem of Changbai Mountains, Acta Ecol. Sin. 24 (10) (2004) 2211-2216.

[3] P.B. Camargo, S.E. Trumbore, L.A. Martinelli, Soil carbon dynamics in regrowing forest of eastern Amazonia, Global Change Biol. 5 (1999) 693-702.

[4] G. Wu, J. Wei, H. Deng, J. Zhao, Nutrient cycling in an Alpine tundra ecosystem on Changbai Mountain, Northeast China, Appl. Soil Ecol. 32 (2006) 199-209.

[5] J. Wei, G. Wu, H.-B. Deng, J.-Z. Zhao, Spatial pattern of soil carbon and nutrient storage at the alpine tundra ecosystem of Changbai mountain, China, J. For. Res. 15 (4) (2004) 249-254.

[6] J. Wei, G. Wu, H. Deng, Vegetation biomass distribution characteristics of alpine tundra ecosystem in Changbai Mountains, Chin. J. Appl. Ecol. 15 (11) (2004) 1999-2004.

[7] J. Wei, H.-B. Deng, G. Wu, Y.-J. Hao, The distribution of soil carbon and nutrients in alpine tundra ecosystem on the northern slope of Changbai Mountains, Chin. J. Soil Sci. 36 (6) (2005) 840-845.
[8] G.F. Shao, H. Qian, Q.J. Liu, The biomass of early spring herb in Korean pine-broadleaf forest in Changbai mountain, in: Z. Wang (Ed.), Forest Ecosystem Research, China Forestry Press, Beijing, 1992.

[9] G.F. Shao, G. Zhao, S. Zhao, H.H. Shugart, S. Wang, J. Schaller, Forest cover types from landsat ${ }^{\mathrm{TM}}$ imagery for Changbai Mountain area of China, Can. J. For. Resour. 26 (1996) 206-216.

[10] B.S. Aaron, L. Robert, Sanford Jr., Soil nutrient differences between two krummholz-form tree species and adjacent alpine tundra, Geoderma 102 (2001) 205-217.

[11] R. Aerts, F.S. Chapin, The mineral nutrition of wild plants revisited: a re-evaluation of processes and patterns, Adv. Ecol. Res. 30 (2000) 2-67.

[12] J.M. Anderson, J.I. Ingram, Tropical Soil Biology and Fertility: A handbook of Methods CAB International, Wallingford, UK, 1989.

[13] L.T. Benjamin, B. Robert, M. Nathalie, S. Sofie, A.W. Brian, Phosphorus compounds in subarctic Fennoscandian soils at the mountain birch (Betula pubescens) tundra ecotone, Soil Biol. Biochem. 36 (2004) 815-823.

[14] T.W. Berger, C. Neubauer, G. Glatzel, Factors controlling soil carbon and nitrogen stores in pure stands of Norway spruce (Picea abies) and mixed species stands in Austria, For. Ecol. Manage. 159 (2002) 3-14.

[15] A.M. Carol, R.B. Geoffrey, M.F. Julia, H. Kenny, Short-term changes in soil nutrients and vegetation biomass and nutrient content following the introduction of extensive management in upland sown swards in Scotland, UK, Agric. Ecosyst. Environ. 106 (2005) 331-344.

[16] H. Cattle, J. Crossley, Modelling of arctic climate change, Phil. Trans. Roy. Soc. Lond. A 352 (1995) 201-213.

[17] F.S. Chapin, G.R. Shaver, A.E. Giblin, K.J. Nadelhoffer, J.A. Laundre, Responses of arctic tundra to experimental and observed changes in climate, Ecology 76 (1995) 694-711.

[18] X.W. Chen, B.L. Li, Change in soil carbon and nutrient storage after human disturbance of a primary Korean pine forest in Northeast China, For. Ecol. Manage. 186 (2003) 197-206.

[19] D. Claudine, G. Marcel, B. Bruno, Effects of experimental small-scale habitat fragmentation on above- and below-ground plant biomass in calcareous grasslands, Acta Oecol. 27 (2005) 49-56.

[20] K. Cromack, R.E. Miller, O.T. Helgerson, Soil carbon and nutrients in a coastal Oregon Douglas-fir plantation with red alder, Soil Sci. Soc. Am. J. 63 (1999) 232-239.

[21] B. Dan, G.R. Michael, Net primary production and nutrient cycling in replicated stands of Eucalyptus saligna and Albizia facaltaria, For. Ecol. Manage. 112 (1998) 79-85.

[22] E.A. Davidson, P.A. Matson, P.M. Vitousek, Processed regulating soil emission of $\mathrm{NO}$ and $\mathrm{N}_{2} \mathrm{O}$ in a seasonally dry tropical forest, Ecology 74 (1993) 30-139.

[23] E. Frossard, M. Brossard, M.J. Hedley, Reactions controlling the cycling of $\mathrm{P}$ in soils, in: H. Tiessen (Ed.), Phosphorus in the Global Environment: Transfers, Cycles and Management, Ellis Horwood Chichester, New York, 1995, pp. 23-27.

[24] A. Gastine, J. Roy, P.W. Leadley, Plant biomass production and soil nitrogen in mixtures and monocultures of old field Mediterranean annuals, Acta Oecol. 24 (2003) 65-75.

[25] H.S. Glazebrook, A.I. Robertson, The effects of flooding and flood timing on leaf litter breakdown rates and nutrient dynamics in a river red gum (Eucalyptus camaldulensis) forest, Aust. J. Ecol. 24 (1999) 625-635.

[26] C. Gordon, J.M. Wynn, S.J. Woodin, Impacts of increased nitrogen supply on high arctic health: the importance of bryophytes and phosphorus availability, New Phytol. 149 (2001) 461-471.

[27] L.B. Guo, R.M. Gifford, Soil carbon stocks and land use change: a meta analysis, Global Change Biol. 8 (2002) 345-360.

[28] M. Holmer, P. Storkholm, Sulphate reduction and sulphur cycling in lake sediments: a review, Freshwater Biol. 46 (4) (2001) 431-451.

[29] R. Jacques, M. Renato, C.-B. Micheline, F. Nathalie, G. Dominique, The dynamics of biomass and nutrient accumulation in a Douglas-fir stand studied using a chronosequence approach, For. Ecol. Manage. 72 (1995) 167-183.

[30] P. Jiang, J. Ye, H.B. Deng, G.F. Cui, Variations of population structure and important value of the main edificators along the elevation gradient on the northern slope of Changbai Mountain, J. For. Res. 14 (2) (2003) 117 121. 
[31] F.D. Joanna, C.S. Mary, C.J. Straker, Nutrient cycling in a Pinus patula plantation in the Mpumalanga Province, S. Afr. Appl. Soil Ecol. 20 (2002) 211-226.

[32] C. Johannisson, D.D. Mayrold, P. Hogberg, Retention of nitrogen by a nitrogen-loaded Scotch pine forest, Soil Sci. Soc. Am. J. 63 (1999) 383-389.

[33] S. Jonasson, A. Michelsen, Nutrient cycling in subarctic and arctic ecosystems, with special reference to the Abisko and Tometrask region, Ecol. Bull. 45 (1996) 45-52.

[34] N. Jose, N. Juan, J. Enrique, Preliminary estimates of biomass growth in the Tamaulipan thornscrub in north-eastern Mexico, J. Arid Environ. 47 (2001) 281-290.

[35] N. Montes, C. Ballini, G. Bonin, J. Faures, A comparative study of aboveground biomass of three Mediterranean species in a post-fire succession, Acta Oecol. 25 (2004) 1-6.

[36] K.J. Nadelhoffer, L. Johnson, J. Laundre, A.E. Giblin, G.R. Shaver, Fine root production and nutrient stock in wet and moist arctic tun- dra as influenced by chronic fertilization, Plant Soil 242 (2002) $107-$ 113.

[37] K.B. Piatek, H.L. Allen, Nitrogen mineralisation in a pine plantation 15 years after harvesting and site preparation, Soil Sci. Soc. Am. J. 63 (1999) 990-998.

[38] I.K. Schmidt, S. Jonasson, A. Michelsen, Mineralization and microbial immobilization of $\mathrm{N}$ and $\mathrm{P}$ in arctic soils in relation to season, temperature and nutrient amendment, Appl. Soil Ecol. 11 (1999) 147-160.

[39] Z.A. Xu, A periodic summary of the research on forest ecosystems on Changbai Mountain, Res. For. Ecosyst. 6 (1992) 1-13.

[40] F.L. William, M.F. Philip, G.L. Susan, Relationship between soils and Amazon forest biomass: a landscape-scale study, For. Ecol. Manage. 118 (1999) $127-138$.

[41] X. Zou, D. Binkley, B.A. Caldwell, Effects of dinitrogen-fixing trees on phosphorus biogeochemical cycling in contrasing forsts, Soil Sci. Soc. Am. J. 59 (1995) 1452-1458. 